\title{
Review article: Between Babel and Globalisation
}

\author{
By S. A. J. Bradley
}

Tandra Mitra, Asoke Bhattacharya and Jayanti Alam (eds), Education and Development: Proceedings of the Grundtvig International Conference held at Jadavpur University in January 1999 (Jadavpur University, Kolkata, India 2003), 176 pp., 11 papers with Foreword, Preface, Introductory Addresses and List of Contributors.

Readers should not let themselves be put off by the occasionally nonBritish English of this book. Its authors and editors are all, with one exception, working in English as at best a second language. This is not to apologise on their behalf: it is to draw attention to precisely the kind of cultural dilemma that the 1999 Jadavpur conference - on the exportability of Grundtvig's educational ideas - addressed. Certainly, various typographical slips have got past the editors; but here editors, authors and readers alike - together with the would-be importers and exporters of Grundtvig - are face to face with a cultural problem as ancient as Babel. As one contributor (Holger Bernt Hansen, 'Grundtvig: Life Enlightenment and Democracy') pertinently asks, with Grundtvig's enshrinement of his Danish mother-tongue in mind: Can a foreign language be the carrier of a common system of values? or is it possible to generate Folkelighed in a language which is alien to the people involved?

Amid the diversity of tongues English is a lingua franca, a necessary tool; and yet, both historically and presently, it is an instrument of colonisation, cultural as well as economic, political and military. Once, as several contributors mention, it was primarily British imperialism ("How relevant the following words are for the anglophiles of India" exclaims one article, prior to quoting Grundtvig's contempt for "an idolization of Latin literature"); now, as none of the contributors mentions, it is American (see, for example, the mission-statement of America's neoconservative Project for the New American Century http://www.newamericancentury.org - "that American leadership is good both for America and for the world"). Add to all this the intrinsic unlikelihood of nineteenth-century solutions proving serviceable in the twenty-first century, or of Christian and Nordic presumptions cutting much ice with more southerly, easterly, Islamic or Hindu cultures, and one might well wonder whether import and export of Grundtvig are even worth starting to discuss. 
For their part, the speakers at the 1999 Jadavpur conference who came together from India, Denmark, Sweden and England, were well aware of the political and cultural-linguistic complexities of such attempts to collaborate as neighbours and would-be friends in the village of the world. But still, they evidently share a conviction that there are indeed universal and transferable values embodied in the Dane Grundtvig's Danish-language response to peculiar Danish domestic circumstances in the nineteenth century.

Painfully clear, at the outset, is India's need for an education system which does not have to wait upon initiatives and resources from central administration, but which harnesses self-help and adapts to local needs, especially in the vast, remoter rural areas. According to Asoke Bhattacharya and Tandra Mitra (then Director and Assistant Director, respectively, of the Department of Adult, Continuing Education and Extension, Jadavpur University, hosts of the conference) in 'Indian Perspective of Adult Education - Relevance of Grundtvig,' India possesses 300 million illiterate people which is more than fifty percent of the world's illiterate population and a third of the whole Indian population. Literacy is empowerment, as all the contributors, including the dignitaries (led by Vice-Chancellor Professor A. N. Basu) who prefaced the conference with supportive and exhortatory addresses, reiterate. Illiteracy is discriminatory, and statistics tabled by Pabrita Sarkar ('India's Literacy Scenario - Achievement and Failure') show it is particularly so for women; yet the irony is, as Sarkar observes, that "the child of an illiterate mother does not remain illiterate." Women, that is, are highly effective educators - a view boldly acknowledged in "The Svendborg Manifesto' published in 1998 by Danish Non-Governmental Organisations dedicated to aiding developing countries, and reported here by Niels Jørgen Jensen ('People's Enlightenment in a Grass-Roots Perspective - The Svendborg Manifesto'), which declares as the second of five 'themes' that "women should be taken as the focal point of learning and education."

The conference entailed much hand-wringing by several Indian speakers. Ratneswar Bhattacharya ('A brief Note on Grundtvig') gives a disconsolate view of the status of adult educators in the Indian educational scene and of the history of literacy in India (including the disastrous British colonial imposition of an elite-creating 'English' education); and Alok Kumar Sinha ('Education and Development: Problems and Strategies') forcefully indicts a failure of will and policy in post-independence India (especially in rural areas), and criticises the 
universities for their diffident implementation of community responsibilities, but also, above them, Government bodies for failing to coerce efficiency, so that the system produces too many graduates and postgraduates unable to contribute to the economy of the nation.

So the need is overwhelmingly evident - but does Grundtvig offer any solutions? Readers who know their Grundtvig and their Kold will spot the relevance in Sarkar's praise (tellingly based on first-hand experience of working in the field) for the effectiveness of oral techniques in previous initiatives to recruit people to literacy classes - and likewise in Sarkar's regret that in the classroom the teachers then turned instead to reliance upon textbooks, and used examination systems to test not understanding but knowledge of these textbooks. Sarkar appears to agree tacitly with what R. Bhattacharya declares explicitly: "This country requires persons like Christen Kold for our literacy programme." For those less familiar with Grundtvig's specific ideas and the values actually practised by Christen Kold and developed through the folkhighschool system, valuable resumés are afforded by A. Bhattacharya and Tandra Mitra, and by Lilian Zøllner ('Grundtvig - Life Enlightenment and Democracy').

In fact, as Mitra and Bhattacharya vividly tell, organised adult education in India has early nineteenth-century origins predating Grundtvig-Kold innovations in Denmark, though a further century of imperial rule was to follow before India saw initiatives broadly reminiscent of the latter - in the shape of attempts to encourage selfreliance through education among village folk, the formation of a cooperative rural bank, a night-school in a village of the untouchables, revival of traditional crafts, and so on. These initiatives were inspired by the vision and backed by the material resources of the charismatic Rabindranath Tagore. Though, as practical gestures, merely a drop in the ocean, the vision was handed on to others. Direct contact with Denmark, and formal study of the history and achievement of the Danish folkhighschool system, have played their part. Tagore visited Denmark, for example, and the Indian University Education Commission (1948-49) advocated looking to the model of "the People's Colleges [= folkhighschools] of Scandinavian countries, especially to those of Denmark" which had been hailed as "the only great successful experiment in educating the masses of a nation."

But what can be, what is being, transferred? The doyen of Grundtvigorientated educational study, K. E. Bugge ('Education and Development: Future, Past and Present in N. F. S. Grundtvig's Educational Thinking'), 
basing an analysis of Grundtvig's ideas of a new 'school for life' partly upon The Academy in Soro. A Sweet Dream by N. F. S. Grundtvig (183738 ), is cautious about adopting a prescriptive role towards developing countries with their complex range of special local circumstances and needs, but is confident enough in his experience in the field to affirm the supportive capacity of such a folkhighschool concept of education for democratic political, social and economic development where local initiative has given a start to this development.

J. H. Schjørring ('Grundtvig's Educational Ideas and their Relevance for India Today') begins, like Bugge, with the plainest declaration of the impracticability (let alone the presumption) of trying directly to equate Danish nineteenth- and Indian twentieth-century - circumstances. This is indeed a theme of the whole book. But he likewise stresses the viability of the folkhighschool concept of education for life, as opposed to an education constricted to a narrow concept of utility. In a lucid and perceptive review of Grundtvig in historical-ideological context he argues that the Danish folkhighschools at their best have nurtured a concern for enlightenment in the deepest sense, which touches the deeper structures in the individual. This answers to a need that is universal; and the educational formula which can deliver this benefit is what has proved to be powerfully adaptable in communities far from Denmark's frontiers.

Alok Kumar Sinha, in his hard-hitting paper 'Education and Development: Problems and Strategies', mentioned above, lists eight recommendations - challenges, one might fairly say - for the revamping of the Adult Education Programme in India (some of which, incidentally, are reminiscent of the needs and the proposed remedies of nineteenthcentury Denmark) in which Grundtvig-Kold principles and practice could certainly play an effective part. Lilian Zøllner ('Grundtvig - Life Enlightenment and Democracy', above) identifies four essential criteria for assessing whether Grundtvigian educational values have indeed been transplanted into Third World programmes: inculcation of freedom and reciprocal responsibility; status of dialogue and conversation as a key process in educational enlightenment; nurturing of a nation's own cultural identity; and the right of a population to use its own language to obtain an understanding of their own cultural identity. She is not entirely cheered by the evidence for the acceptance of these values "in most poor countries."

Mai-Lis A. Follér ('The 'Third Task' - Prospects of Co-operation between Goteborg and Jadavpur Universities') of the Grundtvig Institute in Göteborg University interestingly links the 'extension' commitment of 
Jadavpur with the 'third task' of the Swedish universities stated in the Swedish Higher Education Act - essentially outreach, direct service of the university to the community - and in both finds scope for fulfilment of Grundtvig's concept of livsupplysning (enlightenment/education for life): education as empowerment is a theme in Sweden as in India.

Various Scandinavian contributors, in fact, suggest explicitly or tacitly that the curricular status given by Grundtvig and Kold to traditional indigenous culture in the mother-tongue ensures that the export of the Grundtvig-Kold educational model is transparently free from motives of cultural colonialism. A. M. Allchin ('Education for Life: The Place for Religion and Spirituality') who presumably bore the burden of being the sole Brit present to receive the various brickbats lobbed at the British Raj from all quarters, takes as his starting point quotations from the Sanskrit Bhagavadgita and sketches a fine philosophical characterisation of the Grundtvig who will not fit into conventional categories, and of the thoughts on head, heart and hand which underpin Grundtvig's views on education. Placing alongside the poetry of Rabindranath Tagore an analysis of Grundtvig's poem, 'A simple, cheerful, active life on earth' (Et joevnt og muntert, virksomt liv på jord), Allchin finds common ground and common cause among the poet-philosophers and poet-prophets, and gives material body to the concern of such as Schjørring and Bugge for accommodation of the spiritual, the literary and imaginative, the aesthetic, in any transplantation of Grundtvig and folkhighschool ideals into the Third World.

But the most challenging of the papers must surely be that of Holger Bernt Hansen. With the authority of one who has worked for some years in Danish overseas development assistance he takes an unblinkingly pragmatic look at all those issues touched on by other contributors. In promoting adult education abroad, are we exporting a western model of democracy? And is it true that Denmark has special position, entitlement, qualification, to export the folkhighschool to developing countries? Do we delude ourselves that democracy can function under conditions of great poverty and illiteracy? He regards it as axiomatic that "the educated elite's monopoly on power should be broken" by opening up education to general access. He is prepared to believe, though hesitantly, that there is an effective role for exported educational models and expertise. But he steps well back from the position of the zealous 1960s when some believed that Denmark "as a noncolonial power" (it would be a digression here to carp, as one might, over this claim to clean hands) had a duty to promote adult learning in the developing world because "the 
folkhighschools are our most important export product." He sketches the remarkable instance of Dr Kachi Ozumba and his Grundtvig Institute in Nigeria where Grundtvig-Kold principles (for example, oral communication, use of history and folklore) and Grundtvigian idiom (the 'black school' or 'school of death' - the elitist colonial education system, imposed over the head of the village elder), have served well. But this and other specific case histories teach that carbon copying will not work, and the author is led to define two ways ahead as regards the exportability of Grundtvig, which to many will seem like throwing out the baby with the bathwater: the exporters must drop Grundtvig's distinctive and "very own categories of nation, language, mythology, etc" and then they must abandon the nineteenth-century idea of "national awakening" and substitute "democratic awakening." He concludes with a warning, the point of which has only sharpened the more, in Denmark, in Europe and in the world, during the period since the lecture was given - a warning against fundamentalism in the reading of history.

It is a striking fact that this book, though it is published from out of India and quite properly puts India's reception of Grundtvig into the foreground, repeatedly prompts its reflective western readers to reappraise the continuing domestic viability of their own - the exporters' - inherited values and standpoints in a fast-changing world. Even in the short period of time covered in these papers, history is seen to have marched relentlessly onwards: one contributor passingly distinguishes Denmark from India on the grounds that India has the special problem of multiculturalism, but - need the point be laboured? - multiculturalism has rapidly become, in Denmark as in various European nations, a serious test of the adaptability of inherited formulations of cultural identity, and a hot political issue. If this book, with its duality of focus on both the exporters and the importers of Grundtvig's educational ideas, can persuade its reader, whichever 'world' the reader inhabits, that neither present nor future are well served by treating the national history as a received body of certain and absolute values which will guarantee the future as it secured the past and which may be transplanted into other cultures in order to bring about a healthily like-minded world, then despite its flaws the book will prove not only interesting but salutary reading. 